\title{
ABSTRACTS
}

Robert Nicolaï

Donald Winford

Sarah G. Thomason

Salikoko S. Mufwene
Le contact des langues : point aveugle du 'linguistique'.

Présentation du numéro.

Language Contact: A Blind Spot in 'Things Linguistic'.

Presentation of the Issue.

Some Issues in the Study of Language Contact.

This paper provides an overview of various approaches to contactinduced change, and assesses their contribution to a unified theory of the processes involved in such change, and the outcomes they produce. I argue that clarification of the terminology and classifications we apply to contact languages can lead to better understanding of the types of contact languages, and the kinds of process that produce them. I further suggest that van Coetsem's framework offers a more uniform terminology and classification, and that it clarifies the distinction between the two major transfer types involved in contact induced change - borrowing via recipient language agentivity, and imposition via source language agentivity. Failure to distinguish these two mechanisms accurately has negative implications for our understanding of the processes by which various contact languages are created. I apply this model to two broad categories of contact languages, bilingual mixed languages, and creoles, and I argue that the differences in transfer type identified by Van Coetsem correspond to differences in the language production processes underlying the two broad types of contact-induced change. Finally, I suggest that psycholinguistic models of language or speech production can contribute significantly to our understanding of the different processes involved in the creation of different types of contact languages.

Language Contact and Deliberate Change.

This paper explores the process of "negotiation", whereby speakers of two or more languages converge on a partially or entirely shared linguistic system. This process is surely unconscious in many or most instances, but sometimes speakers are aware of what they are doing as they "negotiate" the linguistic outcome of language contact. I provide evidence for the latter assertion, and discuss the difficulties inherent in any attempt to generalize about conscious vs. unconscious negotiation. I also contrast the process of negotiation with some other views of linguistic convergence. Finally, summarizing previous results, I argue that the existence of deliberate contact-induced (and other) linguistic change vitiates all efforts to achieve a deterministic predictive theory of contact-induced language change.

Population Movements and Contacts in Language Evolution.

I argue for uniformitarianism (Mufwene 2001) in accounts of language evolution. Below, after dismissing a few myths about the development of creoles, I show how what we have learned to date about this case of language speciation prompts genetic linguists to reopen the books about language diversification in general and as a concomitant of language death in many cases. I adduce various examples from distant and recent histories to illustrate how population movements and contacts have been a critical ecological factor even in the cases of so-called "internally-motivated" change. The distinction between "internally" and "externally-motivated" language change boils down to a mere sociological contrast once

www. jlc-journal.org 
Bernard Py

Petr Zima

Malcom Ross contact is situated at the inter-idiolectal level, where interactions and negotiations between linguistic systems take place, regardless of whether or not xenolectal features participate in the feature pool. Ultimately, the same mechanisms of competition and selection that apply to linguistic features also apply to languages and dialects. Driven by the ecology of language use, the mechanisms roll the dice not only on how a particular language evolves under specific ecological conditions but also on the vitality of languages.

Apprendre une langue et devenir bilingue: un éclairage acquisitionniste sur les contacts de langues.

Il est ici proposé une synthèse de la problématique acquisitionniste confrontée à la réalité du bilinguisme et du contact des langues dans le cadre d'apprentissages formels et informels appréhendés en situation.Une question fondamentale: "Comment devient-on bilingue lorsqu'on est immergé dans une communauté alloglotte ou diglossique particulière, que l'on y pratique la communication bilingue ou exolingue et qu'on y occupe une position socioculturelle déterminée?». A partir de là, il s'agit de dépasser les notions abstraites d'exposition à la langue cible et de système qui ne prennent pas en compte les circonstances et la contextualisation de l'acquisition; de mettre l'accent sur la pertinence de l'asymétrie de la communication exolingue. On développe alors une réflexion sur la dynamique de l'apprenant qui décontextualise les données linguistiques auxquelles il est confronté afin de constituer un ensemble de ressources stabilisées, fonctionnalisables à toutes fins utiles dans les contextes d'usage. Cela conduit à mettre en question l'intérêt de la notion de compétence, et le bilinguisme se définit alors autrement : par un accès à des ressources (issues de deux langues) actualisables dans des contextes sociaux particuliers.

Why Languages and Contacts?

101

Contacts of human beings using the available codes in definable contact communication situations/models is analytically distinguished from interference of language systems; the former being the object of the anthropology of communication, the latter being in the focus of linguistics. An attempt at a typology is presented for both complexes, in this paper.

Contacts of speakers are classified according to their intensity/quantity, their quality, and their stratification. Interference types of language systems are classified in terms of their intensity/quantity, and their quality. These general typologies are illustrated by data available from different contact and interference areas and/or language structures current in Europe or Sub-Saharan Africa.

Calquing and Metatypy.

116

Metatypy, meaning 'change in type' is a diachronic process in which the syntactic system of one of a bilingual community's languages is restructured so that it more closely resembles the syntax of its speakers' other language. It is thus a language contact phenomenon. In this paper I deconstruct my earlier account of metatypy and show that metatypy is preceded chronologically by lexical and grammatical calquing but is separate from these processes. Thus there are languages which have undergone widespread grammatical calquing but have stopped short of metatypy. The article also examines alternative terms for metatypy and indicates why I believe that the term 'metatypy' is preferable to them and useful for the subdiscipline of contact linguistics. Associated with this is a proposal that contact linguists adopt a strong hypothesis to the effect that bilingual speakers do not copy single constructions from one of their languages to the other on a

www. jlc-journal.org 


\section{Marianne Mithun}

Lorenza Mondada piecemeal basis but that they always restructure larger systems. This hypothesis is put forward as a basis for research, not as a statement of belief.

Grammar, Contact and Time.

144

A continuing issue in work on language contact has been determining the relative borrowability of various structural features. It is easy to imagine, for example, how a tendency to use particular word order patterns in one language might be replicated by bilinguals in another, but difficult to understand how abstract morphological structures could be transferred. When we look at linguistic areas, however, we often find grammatical features shared by genetically unrelated languages that seem unborrowable. Here we consider the importance of adding the dimension of time to investigations into the potential effects of contact. As a point of departure we examine a relatively straightforward example from western North America, a striking parallelism in verbal structure among large numbers of languages indigenous to California. The example illustrates the fact that parallel grammatical structures in neighboring languages need not have been borrowed in their current form. They might instead be the result of an earlier transfer of patterns of expression that set the stage for subsequent parallel developments.

Le code-switching comme ressource pour l'organisation de la paroleen-interaction.

The aim of the paper is both to present existing research in interactional linguistics and to highlight some broader issues it raises for general linguistics. Thus, code-switching is dealt with not just as a particular phenomenon, but as a key area of study revealing important contemporary issues for linguistics.

Plurilingualism has been approached from several perspectives: among them, the interactional approaches have focussed their inquiries on code-switching as it can be observed in naturally occurring interactional materials, recorded in various social settings. This empirical base has been fruitful for the exploration not only of the socio-pragmatic functionalities of code-switching but also for a redefinition of the grammatical resources involved in the organization of talk-in-interaction. In order to present these contributions, the paper will sketch some approaches coming from a broad interactional perspective, and develop more explicitly the approach inspired by conversation analysis.

This leads us to formulate a series of issues to which code-switching can contribute in a powerful way:

- issues dealing with the very definition of what the grammatical resources are: code-switching is not just the use of two or more codes by the speakers, but involves the active reconfiguration of what a "code" or, better, what a grammatical resource can be - as a flexible, indexical resource endogenously and locally redefined by the speakers for the practical purposes of the interaction.

- issues dealing with the accomplishment of identities and social categories in interaction, dealt with as the emergent product of locally organized socio-linguistic practices ;

- issues dealing with the organization of sequentiality of talk-ininteraction : the way in which code-switching is mobilized both adjust and shape the interactional order and can teach us much about it.

These issues are discussed by referring to the state of the art of this field and to the detailed analysis of a few excerpts of naturally

www. jlc-journal.org 
occurring interactions recorded at work.

Robert Nicolaï

Contacts des langues et contact dans la langue : hétérogénéité, construction de l'homogène et émergence du 'linguistique'.

Les travaux sur le contact des langues donnent peu de place aux recherches sur les variations diastratiques et diaphasiques or, ces phénomènes sont concernés par cette problématique. Je tente de montrer que leur approche permet d'élargir le débat en questionnant des procès essentiels tels ceux de la construction du sens et de la sémiotisation des formes et je me propose d'appréhender le contact de ce point de vue.

Je partirai d'un exemple simple puis, je présenterai ensuite l'arrièreplan conceptuel qui me conduit à ouvrir le débat : il s'articule autour de trois approches qui ont un rapport avec la dynamique des langues et qui gagnent à être liées : l'approche de la 'discursivité', celle de la 'variabilité' et celle du 'feuilletage'. Chacune d'elles privilégie un point de vue sur le fonctionnement de la communication humaine mais toutes trois s'intéressent au fait que dans l'espace global de la communication et en rapport avec la multiplicité des formes langagières et/ou linguistiques actualisées ou potentielles, finissent par émerger des formes, des représentations et des façons de parler qui présupposent l'existence nécessaire d'un contexte de contact interne au développement linguistique lui-même. Je tenterai de montrer que, loin d'être limité à des cas de figure qui impliquent la saisie d'un rapport entre des langues différentes, le contact se situe tout d'abord dans le dynamisme même qui conduit aux langues. Finalement, je présenterai le cas de l'indoubill qui, à une autre échelle, montre la pertinence de la problématique du contact, exemplifie la construction d'entités homogènes au travers d'une hétérogénéité manifeste, suggère quelques ouvertures de recherche et rejoint le questionnement sur le contact entre les langues. 